University of Nebraska - Lincoln

DigitalCommons@University of Nebraska - Lincoln

Faculty Publications and Creative Activity, School of Art, Art History and Design

Art, Art History and Design, School of

2015

Previously Undocumented Art Criticism by Walt Whitman

Wendy J. Katz

Follow this and additional works at: https://digitalcommons.unl.edu/artfacpub

Part of the American Art and Architecture Commons, American Literature Commons, and the American Popular Culture Commons

This Article is brought to you for free and open access by the Art, Art History and Design, School of at DigitalCommons@University of Nebraska - Lincoln. It has been accepted for inclusion in Faculty Publications and Creative Activity, School of Art, Art History and Design by an authorized administrator of DigitalCommons@University of Nebraska - Lincoln. 


\section{WALT WHITMAN \\ QUARTERLY REVIEW}

Volume 32 | Number 4 (2015)

pps. $215-229$

\section{Previously Undocumented Art Criticism by Walt Whitman}

Wendy J. Katz

ISSN 0737-0679 (Print)

ISSN 2153-3695 (Online)

Copyright @ 2015 Wendy J. Katz

\section{Recommended Citation}

Katz, Wendy J. "Previously Undocumented Art Criticism by Walt Whitman." Walt Whitman

Quarterly Review 32 (2015), 215-229. https://doi.org/10.13008/0737-0679.2171

This Essay is brought to you for free and open access by lowa Research Online. It has been accepted for inclusion in Walt Whitman Quarterly Review by an authorized administrator of lowa Research Online. For more information, please contact lib-ir@uiowa.edu. 


\title{
PREVIOUSLY UNDOCUMENTED ART CRITICISM BY WALT WHITMAN
}

\author{
WENDY J. KaTZ
}

Whitman's "Letters From a Travelling Bachelor," written for the New York Sunday Dispatch (October 14, 1849, through January 6, 1850) are well known, as is his practice of contributing news about Brooklyn and Brooklyn artists to the Dispatch as well as to other newspapers like the Evening Post. ${ }^{1}$ But his extended description of a painting by Jesse Talbot, Encampment of the Caravan, in the Evening Post ("Encampment of the Caravan," April 29, 1851; p. 1), and his critique of the National Academy of Design annual exhibition in the Dispatch of the following year ("An Hour at the Academy of Design," April 25, 1852; p. 2), as well as the response the latter generated, have not been cited or described. These articles point to an additional source for Whitman's interest in Egypt and the Orient, and to his eventual disenchantment with institutions for "elevating" popular taste in art.

The Sunday Dispatch (1845-1861) was an inexpensive (3 cents until 1854, then 4 cents) weekly edited by Amor J. Williamson and William Burns (with a third partner, Watson, as co-proprietor), who had also partnered to edit the Weekly Universe (1847-1852). The Universe described itself as "A Cosmopolitan Hebdomadal, only $\$ 1$ a year, Devoted to Literature, Science, Arts, History, Biography, Anecdotes, Amusements, Adventures; and Intelligence, Metropolitan, National and Cosmopolitan." Its Whitmanesque motto was "No Pent-Up Continent Contracts our Powers; But the Whole Boundless Universe is Ours." When Burns died on June 23, 1850, Williamson continued editing both papers, though he eventually dropped the Universe. ${ }^{2}$ Anson Herrick, founder of the Atlas, the grandfather of the Sunday papers, in his history of the Sunday press, noted that Burns had worked for him, as had Whitman (briefly, at the Aurora), Louis Tasistro (the Dispatch praised Tasistro, and Whitman would later solicit money for him), and several of the editors of the Sunday Mercury. ${ }^{3}$ Herrick, a Democrat with freesoil sympathies, disapproved of the turn Amor J. Williamson's politics had taken-Williamson was an active Whig by 1852 .

In the opening issue of the Dispatch, the editors, after pointing out that each of them was over six feet tall, introduced their editorial policy. Whereas party (partisan) editors look at political documents as party 
artists look at a picture, "in different lights," with amusingly absurd results, the Dispatch argued that there is a true light in which to survey pictures and political messages - the light of nationality and progressive democracy. ${ }^{4}$ They reproduce in that same month an excerpt from author Cornelius Mathews' speech on Young America, in which he describes Young Americans as the first race (generation) of republicans in birth, origin, education, and experience, making each man in some sense the Republic himself. By 1848, they announce that "we are radical in the extremest degree," working for something better than this "vaunted civilization." "The Dispatch supported free public baths and land reform, published Bryant poems, admired Kossuth and Garibaldi, was sympathetic to the filibusters like William Walker, got involved in a libel case with James Gordon Bennett of the Herald, hated Fernando Wood, and was critical of laws restricting business on Sundays. ${ }^{6}$

In regards to art, by 1849 the Dispatch was increasingly dismissive of the American Art-Union-an organization to promote the arts headed for many years by William Cullen Bryant but mostly governed by Whig merchants - as an institution of privilege. The editors pointed out, for example, that the Art-Union's annual lottery of paintings was permitted by the legislature, while small lottery offices catering to the poor were raided by the police. Furthermore, they argued that a clique of artists-cliques being consonant with undeserved privilege-controlled the men who ran the Art-Union, and so biased its patronage. Other anecdotes imply that the Art-Union gallery was a place for romantic trysts. Similarly, the Dispatch vigorously attacked the American Institute, which annually exhibited the mechanical arts and had a similar structure - it was run by Whig manufacturing interests rather than by the mechanics it was supposedly benefitting. ${ }^{7}$ The editors more generally mock wealthy would-be connoisseurs of the arts, contrasting them with a viewer "I" who presumably better represented their readership and who found in art a sense of political inspiration. As part of a series on "Scenes and Sights in New York," for example, a collection of paintings on Broadway is recommended. Though its images from Cooper's Spy would seem crude and not much to the "eye of the connoisseur," the author says that still "I gazed long and earnestly upon them!"-with blood hastening, heart throbbing, and head becoming more erect. ${ }^{8}$ The Dispatch also had reviews of the artist-run National Academy of Design's annual exhibition, and in one of these it praised William Sidney Mount, Henry Kirke Brown, and even gave Whitman's future brother-in-law Charles Heyde's paintings mostly good reviews. ${ }^{9}$

Indeed by 1850, the Dispatch was well enough known for its criticism that the Lorgnette satirized the Fashionable Man, who in order to show himself a master of town taste on all subjects, including the fine arts, picked up a "carefully prepared round of critiques" at his clubs, 
where he read the "Home fournal, the Dispatch, the Evening Post." The Home fournal was edited by Nathaniel P. Willis and George P. Morris, known for both their prose and verse, while the Evening Post had William Cullen Bryant and Parke Godwin. ${ }^{10}$ The Dispatch, perhaps the least remembered of the three today, had Charles B. Burkhardt as its music critic and perhaps art critic-he was at least a member of the Sketch Club by $1849 .{ }^{11}$ All three journals, in 1850 , had what might be considered literary pretensions and at least former associations with Democratic politics. These two previously undocumented articles on art by Whitman for the Post and Dispatch show him exhibiting the style of the newspaper art critic, who turns art into controversy and advocacy; but they also highlight how and perhaps why he departed from this model. ${ }^{12}$

Whitman was actively involved with the visual arts in the years before Leaves of Grass; Ruth Bohan estimates one-third of his writing referred to it. In 1850, for example, under the pseudonym Paumanok he wrote a series of articles for the anti-slavery National Era (published in Washington D.C.), which included a review of the current American Art-Union exhibition in New York, in the context of describing various sights of the town. ${ }^{13}$ Even the title "An Hour at..." was used frequently by Whitman for his other urban journalism, which suggests that he saw this Dispatch piece as part of his larger project of commenting on the significance of the various views and places of Brooklyn and New York, not altogether unlike his later series "City Photographs." ${ }^{14}$ Whitman also wrote supportive descriptions of the artist-run Brooklyn Art Union and in 1851 was asked to address the Brooklyn society, which, like its New York City contemporary, exhibited artworks without the usual 25-cent gallery admission, making them more accessible to more people. ${ }^{15} \mathrm{His}$ address, like his earlier writings on the fine arts, accordingly emphasized the role of exhibitions in democratizing painting and sculpture.

His writing on art exhibitions seems to have often been triggered by the involvement of his friends. The best known example of this is perhaps Walter Libbey, a genre painter from Brooklyn, who painted a portrait of Whitman. Whitman wrote about Libbey's New Fife, a painting that was bought by the American Art-Union in 1851, for the Evening Post; at that time, editor Bryant was still president of the Art-Union. In the 1853 legislative investigation of the Art-Union's practices, Libbey was named as one of the artists compelled to take low prices for his work. ${ }^{16}$ Many if not most of the artists mentioned at any length in "An Hour at the Academy" seem to have similarly had a personal connection with Whitman. Charles L. Elliott, for example, would also paint Whitman's portrait. ${ }^{17}$ Whitman had shown interest in Thomas Hicks as far back as an 1848 article in the New Orleans Crescent, and Charles L. Heyde, also mentioned albeit briefly, was to become his brother-in-law 
in $1852 .{ }^{18}$ If Whitman had a connection with Erastus Dow Palmer, it has not been documented (though Palmer named a son Walter). But in the same issue of the Evening Post as Whitman's description of Jesse Talbot's Encampment, the City Intelligence editor for the Post promotes Palmer's sculptures, and in 1856 Bryant would invite him to present a one-man show in New York City. ${ }^{19}$

Jesse Talbot, who had a third-floor studio in Post's Building in Brooklyn, is most prominently featured in these and other of Whitman's articles on art in this period. Whitman's print of Talbot's Christian and the Cross (from Bunyan's Pilgrim's Progress) had been engraved by the American Art-Union in 1847, but Whitman doesn't seem to begin writing about him until $1850 .{ }^{20}$ In this previously unknown Whitman essay on Talbot for the Evening Post in 1851, perhaps written to support Talbot's new enterprise, an art school, Whitman extensively describes a painting ("Encampment of the Caravan") apparently still in Talbot's studio, suggesting his familiarity with the artist, and emphasizing the individuality of his style. ${ }^{21}$ Whitman describes the scene as "oriental," with a band of travellers pitching white tents by banana trees, and gathering around a campfire. He also emphasizes that "It is a picture with camels." But Talbot earns the most praise for his mastery of twilight effects, with a rising moon and a dying sun "merged." Interestingly, in "Poem of Salutation" (Leaves of Grass, 1856), Whitman would later write:

I see Teheran, I see Muscat and Medina, and the intervening sands-I see the caravans toiling onward;

I see the curious silent change of the light and shade,

I see distant lands, as real and near to the inhabitants of them as my land is to me. ${ }^{22}$

While he "sees" a lot of things in this poem and in Leaves of Grass generally, including a camel and the tents of nomads, perhaps as he "saw" the marriage of the trapper depicted in "Song of Myself" in a painting by Alfred Jacob Miller, so he saw some of his scenes of the Orient in Talbot's paintings. Perhaps he also saw them in George William Curtis' writings on Egypt and Arabia, a source not often mentioned in connection with Whitman. But Whitman here notes that a "traveller's" suggestions had conferred a degree of accuracy on Talbot's view, and it seems likely that the traveller was Howadji, the name under which Curtis published his travel accounts, including his Nile Notes. ${ }^{23}$

Whitman in this excursus on the Encampment also engages with prior critiques on Talbot. Saying that Talbot's style "is any thing else in the world except a copied style," he refutes what an earlier critic had called a style "so strongly tinctured with plagiarisms that it must be 
noted." That critic, writing for the American Repertory, had accused Talbot in his painting The Happy Valley, from Rasselas, of taking trees from British painter J.M.W. Turner, and other parts from other good masters, and then trying to pass off the whole as an original. Perhaps surprisingly, given this, the same critic's introduction to his review of not just Talbot but that year's whole National Academy of Design exhibition, recommended that artists combat other city papers' unjust faultfindings by filing lawsuits. James J. Mapes, editor of the American Repertory (which cost $\$ 4$ a year, though it claimed to be aimed at mechanics), was a sugar manufacturer and a founder of both the Mechanics Institute and the American Institute, the latter of which came under severe criticism by journals like the Dispatch and the Morning Nerws (edited by John O'Sullivan); a "Mechanic" wrote to the latter about Mapes's speech, accusing him of using the American Institute as a vehicle for Whig party aggrandizement and for capital, rather than for the benefit of artisans. ${ }^{24}$

In the tradition of the journalist and editor for the penny press, then, who specialized in attacking privilege, Whitman is helping to point out overlooked genius, and, in "An Hour at the National Academy," perhaps hints at why it is overlooked-because of the cliques and private interests that control institutions ostensibly serving the public. By contrast with notices of individual artists and their doings, such as Whitman's "Encampment of the Caravan," which is careful to avoid any actual controversy, penny press reviews of the annual exhibition of the National Academy of Design were often more polemical. These exhibitions were understood as a litmus test for the current state of American art, particularly the degree to which native artists were developing a distinctive national character in their art. As the various New York newspapers often had different conceptions of that national character, their criticisms and evaluations often stimulated responses, as Whitman's did from an anonymous writer, who in turn references a review in the Mirror.

To put their dialogue into context, it's worth noting that there was a general disapproval among newspaper critics of not only the quantity of portraits in the 1852 exhibition, but of their quality; the Morning Courier and New-York Enquirer, an influential Whig morning paper, thought that the exhibition was covered with colored canvas in frames too costly for what they contain, which was miserable compounds of conceit and ignorance. Half the portraits, its critic said, were caricatures, and, like the landscapes and figure pieces, only a few rose above mediocrity. That critic singled out among the portraits one by Jared B. Flagg, which he called a charming embodiment of placid content and lady-like repose, which would please cultivated taste. ${ }^{25}$ The Evening Mirror, a Taylorist organ that continued to support Fillmore's administration, objected even more strongly to the "excess" of portraits. But more tellingly, for 
the Evening Mirror, the real problem was that so many of the portraits were from "real, vulgar life, of everyday faces we meet in streets and drawing rooms of the city." These counterfeits of "Snooks," the Mirror feels, are just a step above sign painting, presumably equally mechanical. Surprisingly, though, the portraits it singles out for specific expressions of dislike are not ones of nobodies, but of an ex-Governor (Hamilton Fish, a Whig and a patron of E.D. Palmer) in the act of presenting the Homestead Exemption Bill to the Assembly, and one of General Walbridge. The portrait that is approved is one by Thomas P. Rossiter, which is said to be ladylike, and sweet: mild, serene, soft, and dainty. ${ }^{26}$

Amid this chorus of Whig enthusiasm for the dainty and refined, Horace Greeley's Tribune had a new art critic, George W. Curtis, already a popular writer. His first notice of that year's National Academy exhibition appeared on the same page as one of Karl Marx's letters on Germany, the latter writing in his role as the Tribune's foreign correspondent. As this suggests, though Greeley's paper was Whig, it was considerably more democratic and reform-minded in its sentiments than the Courier and Enquirer or the Mirror. Curtis, who signed his critiques, offered a more professional style of criticism-he laid out his system of judgment in advance-and rather thoroughly over several weeks carried out a systematic analysis of art at the exhibition. Most art critics previously and into the 1850s were more like Whitman, literati (in the phrase of the day), amateurs, editors, or reporters who were friends with artists or who had a bent for the fine arts and wrote occasionally on them. That same year (1852), Curtis mostly waged war on painters like Jasper Cropsey and Asher B. Durand who tried to include allegorical or symbolic elements in their landscapes, but he did agree that portraits were very numerous and very bad. However, for him, while Governor Hamilton Fish is no Apollo, the painter Thomas Hicks is masterly in presenting "living reality" and heroic self-reliance. Curtis' praise of Elliott, though, is faint-Elliott gives great satisfaction to his friends, but his color is not natural, too brilliant, giving his portraits an air of unreality. Curtis does, like Whitman, praise Wandesforde's cold, solemn gloom, or silent desolation, and Palmer's grace of sentiment and sincere feeling. None of these other newspaper critics, however, mentions Talbot. ${ }^{27}$

Whitman's art criticism, then, should be seen not only as intended to support artists unjustly overlooked or misunderstood by other critics, but as countering the definitions of good painting being purveyed by other, often more conservative papers. In an earlier (1850) essay on American art in the Dispatch, which like most of the weeklies was not partisan per se, but strongly liberal if not Democratic in most of its social and political positions, Whitman similarly featured Jesse Talbot. Whitman identifies him as someone who would be among the nation's first artists if it were not for his modesty, and he goes on to praise Talbot's 
painting The Happy Valley, from Rasselas, for its lavishly rich and varied coloring, intense light, exuberantly warm character - a Nature "full of glowing blood." ${ }^{28}$ In that year's review of the Academy exhibition in the Dispatch, the critic similarly praises Elliott for his warmth and truthfulness, but the Academicians who chose the paintings are called stiffnecked and dignified old fogies whose portraits only got in because they were members. Jared Flagg's portrait of a lady is clean and pretty, and that is all. ${ }^{29}$ Whitman's language of warmth, fervor, charged blood, like his dislike of cold correctness, of conventionality as supported by the National Academy, which ran a school for artists and like all schools taught certain rules, is the language of the reformer who speaks for the unrefined against the hierarchical fogies.

The tone of Whitman's respondent in 1852 suggests he might be an artist (he recommends the Academy's school for art) and someone acquainted with Whitman. But while he recognizes Whitman's advocacy for Talbot and Heyde-something not at all uncommon among critics (James Gordon Bennett in the Herald took up the unknown sculptor James V. Stout in 1839 and regularly urged his merits) - he struggles with the thrust of Whitman's argument about nature. ${ }^{30}$ He feels, perhaps understandably, that telling artists to copy nature by studying art (Elliott's portraits) is absurd. But Whitman doesn't quite say that. Instead, he recommends emulating Elliott's style in order to achieve art that is fully charged with life, because he says artists are taught to be fearful of this (Elliott's) sort of luxuriance that exceeds appearances, and so they try to copy nature-and are accordingly dashed on its rocks.

\section{University of Nebraska-Lincoln}

Monday, April 21, 1851, Evening Post, p.1.

[For the Evening Post]

"Encampment of the Caravan."-Jesse Talbot, the landscape painter, has nearly finished a large work of peculiar beauty. The scene is oriental; a band of travellers over the desert has encamped for the night on a luxuriantly fertile oasis, by the banks of a stream whose zigzag windings come from a long distance beyond, down almost directly under the eye of the spectator. The time is just after sunset, the full moon rising in the east, and her light mixing in with the dying halo of day; a new and finely rendered effect. The light falling on the distant water, and the clouds above surrounding the newly risen moon, remind one more of nature than of fine painting. It is doubtful if the parts just mentioned can be surpassed by any living artist.

It is a picture with camels. In the very fore-ground stands one of these patient beasts of the desert, his head high in the air, and his huge body fully and fairly exposed; he has been released from his saddle and burden, and as he stands there, the loose bridle hangs from his under jaw. Very masterly in drawing and its expression of 
repose, is this boldly put figure.

Farther back are other camels, two of them kneeling flat to the ground, and one with his burden not yet lifted from his back. His breast and neck are flushed with the red light of a fire of dry wood kindled at a little distance in front of him, around which men, in the picturesque costume of the east, are busied, or sitting cross-legged. The other camel is free of saddle and baggage, but still lies sprawling on the ground, complacently enjoying his ease.

Nigh where the camels kneel, spring gracefully two vigorous beautiful banana trees, drawn and painted by Mr. Talbot, from nature. Long, long and lingeringly will the eye remain upon these beautiful trees, on their slender stems, and on their broad leaves, an effusion of the royal richness of the drapery of nature. The other trees and foliage, palms and so forth, are well done, but the bananas have a surpassing charm of freshness, beauty and supple youthful vigor.

At the right, are pitched the white tents of the caravan; and spread over the picture appear the peculiar symbols of the glowing vegetable life of the east. A soft and dreamy light envelopes all. It is the legacy of the fiery sun, quietly received and merged, in the flood of pure clear moonlight.

Mr. Talbot's style of painting is any thing else in the world except a copied style; his productions can never be mistaken for another man's. One effect, in particular, is achieved in the picture just described, and, indeed, is a distinctive mark of this artist. It is a likeness of air in the picture; palpable, yet clear sun-warmed air. In this Encampment of the Caravan, a subtle haze, a dreamy precursor of night, is just preceptible [sic].

The perfect pleasure which this work will give to a truly critical taste, need not be forestalled by any high strung praise. Artists and connoisseurs will, doubtless, soon have an opportunity of seeing it, and of seeing whether it is not to be pronounced the best of Mr. Talbot's paintings.

A traveller through Arabia and Egypt, who made many sketches and drawings, and lately returned to the United States, has given Mr. Talbot the advantage of several suggestions and critical hints in the progress of this picture.

W.

Sunday Dispatch, April 25, 1852, p.2.

An Hour at the Academy of Design.

The principal feature of the lately opened exhibition of the National Academy of Design, consists in a fine representation of portraits. The work in this branch of art is some of it superb; and we doubt whether even the galleries of contemporary art, in the great cities of Europe, make a better show in that particular line. Elliott's rich and glowing pictures take the lead, as usual; but closely crowded by the heads of G.A. Baker, in a similar style. There are excellent portraits, also, by Jesse Talbot, F.G. Wright, Blondell, Carpenter, and others.

Perhaps the picture of the exhibition, upon the whole, is Hicks's full length of Governor Fish. It is a splendid production, and worthy to be the property of this proud and wealthy city, to whose order it was painted. Such are the works - so warm and fervent, and under the manifest control of high principles - that our young American students should scan closely and patiently. 
The sculpture of that native-born child of genius, E.D. Palmer, is an American triumph! The two heads and busts he has in the exhibition, at the same time irritate one's appetite for more. They are not merely promises either; they are the ripe fruit of performance.

We desire to give a cheering word to this young scion of New York; and we would spur him to the attempt of something commensurate with the high scope of his talent, and the capacities of that grand and pure art of which he is so true a minister.

The listlessness which attends the exhibition of most sculpture, never affects us when looking at Palmer's work. He is so delicately true to the finest modulations of nature; and so conveys that unnameable something called sentiment. Go onward, sir-onward and upward.

There are some good landscapes in the exhibition by Durand, Kensett, C.L. Heyde, Gignoux, and others. A German named Wandersforde has two wonderful pictures there- "Vespers," and the Scottish "Pass of Glencoe."-We have never seen the effects of depth, sombre shadow, and transparent, receding distances, handled in a more masterly manner.

But, take the landscape department of this exhibition, in the mass, and it by no means evinces what American painters are capable of. Why was not Talbot's "Encampment of the Desert," and other lately finished work of the highest class in art, by various artists, Page among others, that we know to be in the city, secured for this Exhibition? The managers will say, Because they were not sent to it. But, Messrs. Managers, has it never occurred to you that instead of sitting quietly in your armchairs and receiving whatever the winds, good or bad, may blow toward you, it would be far better if some little stir were made on your part, to procure first-rate pieces? It is not a favor at all for you to give audience to a superior performance of a genuine artist; it is rather a piece of grace on the part of the painter.

For the National Academy should not only be the medium for bringing our young artists before the public - which, to give it the credit due, we must say, it does with a fostering and indulgent hand. But it ought also to be the exponent of the best phases of art, in this metropolis: and not only here, but all over the republic. It should show our American genius, with its best foot foremost.

This it does not do, in the present exhibition-always excepting the portraits. It does not, because it has, if we understand the case, been too lazy, and stood too much on the stilts of its dignity. From a habit of sitting like a prince at his levee, to dispense smiles and favors, not to receive them, the Academy is in danger of falling into the serious error of not understanding its own position.

New York is not a provincial city; and its taste in the fine arts has made the leaps of a lion, since this institution was founded. It is rapidly settling into the rank of one of the capitals of the world, with the mighty destiny, perhaps, of being Queen of them all! No city can be truly great which is not made vital by the Fine Arts. With all the bustle of commerce, and the glitter of wealth, the edifice is not complete without them. It wants the sunshine.

Well, if the National Academy assumes to be the artistical steward and exponent of this august mistress, it must show itself more worthy. It must be transposed from a passive to an active existence. Instead of waiting till birds fly into its net, it must go forth and catch them.

To the young artists themselves, we should say that the greatest general deficiency, running all through these galleries - with the signal exception, as aforesaid, 
of the fifteen or sixteen superb portraits-is a premeditated deficiency of fervor and warmth. Many of the pictures are coldly correct, but the blood in their veins moves by rote; and $\mathrm{O}$, so languidly — so tamely. We would have it in jets from the heart - in spasms, if you please-only the real scarlet, charged, to the full. Let Elliott's heads be your text, and apply his spirit to your landscapes, and other compositions. That would not be nature, you say; and you purpose to copy nature. To copy nature! - ah, if you only could.

This sad mistake - this fear of overwhelming with too much luxuriance, because it is not, in the real objects, apparent to the superficial vision-is hung up in multiplied forms through every one of these six galleries. It is the rock where most of the young painters dash, and persist in dashing. W.W.

May 2, 1852, Sunday Dispatch, p.2.

The National Academy.

To the Editors:

Your correspondent, W.W., in the last Dispatch, gave us an article upon the present exhibition of this institution, to which several very just exceptions may be taken, and I shall just take the liberty to point them out. In art, its practice and productions, the just and true journalist must ever carefully avoid personal likings and disliking, must only have an eye to the true merit and worth of the subject which he is called upon to criticise, not the artist who produced the same.

To begin at the beginning, I fully agree with W.W. as to the fine collection of portraits that grace the walls of the Academy, but do not agree with him in subsequent remarks upon the subject of portraits. It has, of late years, become too much of a stereotyped newspaper complaint, it has almost become fashionable to grumble about the abundance of portraits in the annual exhibition, and certainly never was a complaint so unjust, so silly. Our friend would have the Academy "the exponent of the best phases of the art;" and pray where are these to be found if not in portrait painting? Its very title implies close study of nature, truthfulness of coloring, and strict attention to tone and character. I am proud to write it, and beg to have it distinctly known, that in this high branch of art, American painters, nay, young American painters, stand second to none in the world. And where, let us ask for a moment, where except from the ranks of these much abused portrait painters, are we, or is the world to get historical painters? And may we not with pride point, even in this exhibition, to the compositions of Leutze, Rossiter, Huntington, Baker, Thompson and others, whom our friend W.W. seems so strangely to have overlooked. These artists are all portrait painters, nor are their historical or composition pictures aught else but a combination of portraits, a branch of art, which another wiseacre, (he of the Mirror) calls "but a step above sign painting."

Mr. Jesse Talbot seems to enjoy the especial favor and patronage of W.W., and after giving Elliot due credit for his masterly productions, he quickly brings in Messrs. Talbot, Wright, Blondell, Carpenter \&c., for their excellent portraits. I have seen some very creditable productions of Mr. Talbot, but the only head which he has in this exhibition, is unquestionably below mediocrity. Of the other named parties, we should only pick out Mr. Wright, whose very fair pictures should deserve a space in a limited notice, whilst the names of Rossiter, Pratt, Cafferty, Fuller \&c., in the portrait depart- 
ment seem entirely to have escaped notice. Hick's picture of Governor Fish is rich, brilliant, and we had almost said gaudy, at least as far as the head is concerned, but we certainly should not recommend the bad drawing of the legs, which seem wrongly fitted to the body, nor the second-hand, muddy and Chatham-streetish appearance of the old clothes upon him, for imitation and study to young artists.

Come we to the landscapes, and we are again astonished that our friend should have utterly overlooked Cropsey, Church, Johnston, Richards, Gifford, Muller and others, whilst he includes the very mediocre affairs of Heyde in his list. And here again, we have Mr. Talbot's "Encampment of the Desert" thrust at us, among other "works of the highest class of art." Says W.W., complaining of the absence of said great work, that managers ought to be more active, which is absurd.

"The managers will say, Because they were not sent to it. But Messrs. Managers, has it never occurred to you that instead of sitting quietly in your arm-chairs and receiving whatever the winds, good or bad, may blow toward you, it would be far better if some little stir were made on your part, to procure first-rate pieces? It is not a favor at all for you to give audience to a superior performance of a genuine artist; it is rather a piece of grace on the part of the painter."

All this sounds very plausible, and has only one fault, namely absurdity and misrepresentation, as it is not so. Our friend must remember that the government and the hanging committee consist entirely of artists, that the exhibition is solely for the benefit of art and artists generally, and that all have an equal interest in it, and should be equally interested in the exhibition. What artist then, can with propriety go to a brother artist, and urge him to send more pictures, urge him to look after his own interest more than the latter thinks proper. And yet even this has been done, and I know from good authority, that the studios of our artists have all been visited, and that contributions have been solicited from all artists who were in any way accessible. If painters would not do themselves justice in the display, surely the temporary directors cannot be blamed. W.W.'s remarks might be applicable to the Art Union management, but must be unjust from the very nature of the Academy's exhibition.

I have but a word more to say about a queer contradiction in our friend's closing remarks. He charges in one wholesale charge, all our young artists with coldness, a want of fervor and warmth, and recommends them to

"Let Elliot's heads be your text, and apply his spirit to your landscapes, and other compositions. That would not be nature, you say; and you purpose to copy nature. To copy nature! - ah, if you only could."

And could our friend find no other text either for a portrait or a landscape painter, than "Elliot's heads?" Would it not perhaps have been as well to send young artists to the same school where Elliot (himself still a young artist,) learned to paint his heads. And are they to gain that only great desideratum, (of which W.W. makes justly so great a point, and a lamentation) "to copy nature," by painting after Elliot. Henceforth ye landscape painters ascend to the fourth story of the Art Union buildings, to Mr. Elliot's rooms, and get your nature or spirit for the same, and ye young portrait painters go there and fetch your text, and still continue to sigh to your latest age, "copy nature, oh if we only could!" 


\section{NOTES}

1 Joseph Jay Rubin, in The Historic Whitman (University Park: Pennsylvania State Press, 1973), 311-354, indicates that the Sunday Dispatch first published Whitman's (Paumanok's) "Letters from a Travelling Bachelor," and Rubin notes Whitman's contribution "Pickings-up about Brooklyn" to the same paper (242). Whitman also published "Letters from Paumanok" (Evening Post), "Brooklyniana" (Daily Standard) and "Brooklyn Affairs" (Atlas).

2 Whitman's "Resurgemus" appeared in the Weekly Universe on August 10, 1850, p. 4. The Sunday Dispatch and Weekly Universe shared considerable content. Williamson continued the latter as the bimonthly New York Universe: An Independent fournal of the Times (1853-1855), from 22 Beekman St., costing 6 cents, with the same motto.

3 Atlas (May 12, 1861), 2. Edwin Haviland Miller, "Walt Whitman and Louis Fitzgerald Tasistro," Walt Whitman Review, 7 (March 1961), 14-16. The Sunday Mercury, April 10, 1853, and December 13, 1853, added that Oatman, an editor for the Atlas, also became a proprietor at the Dispatch in 1853, and congratulated Herrick, "the hard and soft Democrat of the Atlas," and Williamson, "Whig and reformer of the Dispatch," on their election as Aldermen. Others who worked at the Dispatch may have known Whitman, including T.W. Meighan, who had edited the Sunday Times and Noah's Weekly Messenger with Mordecai M. Noah.

4 Sunday Dispatch, vol. 1, no. 1 (December 7, 1845), 2. The editors see in this progress glimpses of empire, too, and invoke a soul that springs into the twentieth century.

5 "Young America," Sunday Dispatch (December 28, 1845), 1; "Our Fourth Volume," Sunday Dispatch (December 3, 1848), 2.

6 Walter Whitman, “Sunday Restrictions," Sunday Dispatch (October 29, 1854), 1.

7 "Abuses of the Art Union," Sunday Dispatch (March 11, 1849), 2. On lotteries, Sunday Dispatch (February 18, 1849), 2. On trysts, Sunday Dispatch (May 18, 1851), 2. On the American Institute, for example, Sunday Dispatch (June 22, 1851), 2.

8 "Scenes and Sights in New York," Sunday Dispatch (December 3, 1848), 4.

9 On Mount's Fust in Tune, a "rustic beau," (January 6, 1850), 2; on Brown, "National Academy of Design, 2nd article" (June 2, 1850), 4; and Heyde, "National Academy of Design, 3rd article" (June 9, 1850), 2. Whitman wrote about Mount in "Something About Art and Brooklyn Artists," Evening Post (February 1, 1851), signed W.W., in Emory Holloway, ed., The Uncollected Poetry and Prose of Walt Whitman (1921; rpt. Gloucester, MA.: Peter Smith, 1972), 1:236-238; hereafter UPP. Ruth Bohan, Looking into Walt Whitman: American Art 1850-1920 (University Park: Pennsylvania State University, 2006), 217n51 (hereafter, Looking), assigns the unsigned June 2, 1850, Dispatch review of the National Academy to Whitman. This was a multi-part review over several weeks, with accompanying illustrations, which went methodically through almost the entire catalogue of the exhibition. These reviews also appeared as shared content in the Weekly Universe.

10 "Description of the Fashionable Man," Lorgnette, excerpted in the Sunday Mercury (February 7, 1850), 3. Lawyer Donald Grant Mitchell had written mildly satirical travel sketches of Saratoga and resorts in Europe under the pseudonym Ik Marvel, published in various newspapers including the Whig Morning Courier and New-York Enquirer, before starting the periodical The Lorgnette in 1850. During that time he also published the Reveries of a Bachelor. In 1853, he was appointed Consul at Venice 
(Franklin Pierce administration). See Evert Augustus Duyckinck and George Long Duyckinck, Cyclopaedia of American Literature (New York: Charles Scribner, 1855, 2 volumes) 2:701-702.

11 Burkhardt, who may have also worked for the Schnellpost, was an honorary member of the Sketch Club, along with (among others) art critic Charles (Carlos) D. Stuart, Cornelius Mathews, and W.W. Fosdick. The Sun (January 1, 1849), 2, records a semimonthly meeting of the club at Burkhardt's.

12 This mode of writing about a lounge in an art gallery was fairly common in the newspapers; for Whitman examples, see "Matters which were Seen and Done in an Afternoon Ramble," Brooklyn Daily Eagle (November 19, 1846), which includes mention of the Art Union and of Henry Kirke Brown's statuary; reprinted in Holloway, UPP, 1:141-144; Walt Whitman, "April Afternoon Ramble," Brooklyn Evening Star (April 30, 1850); and "An Afternoon Lounge About Brooklyn," Brooklyn Evening Star (May 24, 1852).

13 Bohan, Looking, 18. Paumanok [Walt Whitman], "Letter from New York," National Era [Washington, D.C.] (October 31, 1850). Published in Rollo Silver, "Whitman in 1850: Three Uncollected Articles," American Literature 19 (January 1948), 301-317. Whitman singles out Richard C. Woodville's genre painting Old '76 and Young ' 48 for comment in this anti-slavery newspaper, perhaps because it foregrounds the question of the legitimacy of the expansion of slavery into new territories.

14 Joel Myerson, Walt Whitman: A Descriptive Bibliography (Pittsburgh: University of Pittsburgh Press, 1993), lists "An Hour at a Bath" (Evening Tattler, August 11, 1842); "An Hour in a Balcony" (Aurora, March 23, 1842); "An Hour Among the Shipping" (Brooklyn Eagle, March 5, 1846); "An Hour at a Brooklyn School" (Brooklyn Eagle, May 9, 1846); "An Hour in One of the Brooklyn Public Schools" (Brooklyn Daily Eagle, March 4, 1847); "An Hour Among the Porcelain Manufactories in Greenpoint..." (Brooklyn Daily Times, August 3, 1857); and "An Hour at Kenosha Summit," which is a departure from the city journalism and does not appear in a newspaper but in Specimen Days (1882). Bohan also notes "An Hour Among the Portraits," Brooklyn Evening Star (June 7, 1853). In addition to these, I found "An Hour in Washington Market" in the Weekly Yankee (August 30, 1848), 4, though its language does not seem distinctively Whitmanian; Whitman had written "Life in a New York Market," Aurora (March 16, 1842), reprinted in Herbert Bergman, et al. eds., The fournalism (New York: Peter Lang, 1998, 2 vols,), 1:55-58. “City Photographs," New York Leader, 1862, available online at the Walt Whitman Archive (whitmanarchive.org).

15 "Works of Beauty and Talent-The New Art Union of Brooklyn," Brooklyn Daily Advertiser (April 4, 1850); "Brooklyn Art Union-Walter Libbey-A Hint or Two on the Philosophy of Painting," Brooklyn Daily Advertiser (December 21, 1850). "Art and Artists," Remarks of Walt Whitman, before the Brooklyn Art Union, on the Evening of March 31, 1851, rpt. Holloway, UPP, 1:241-247. See also "Polishing the Common People," Brooklyn Eagle (March 12, 1846); "Free Exhibitions of Works of Art," Brooklyn Daily Eagle (October 21, 1846); and "About Pictures, \&c.," Brooklyn Daily Eagle (November 21, 1846), rpt. Bergman, The fournalism, 1:279-280; 2:94, 128-129.

16 W.W., "Something About Art and Brooklyn Artists," Evening Post (February 1, 1851), rpt. Holloway, UPP, 1:236-238. The article also mentions Long Island artist and Democrat William Sidney Mount. Artworks distributed by the American ArtUnion are listed (among other places) in the New York Times (December 16, 1851), 3. On Libbey being oppressed, see "Art Union Proceedings," New York Times (May 11, 1853), 2; (May 14, 1853), 3, where a testimony is published regretting that "Mr. 
Libby's picture, 'Teasing,' is so universally condemned." Libbey died at age 26 on December 7, 1852, and was buried from his father's house at 124 Prince St., Brooklyn. Whitman also wrote about Libbey in "Brooklyn Art Union-Walter Libbey." Whitman's interest in art of the West, as for example Alfred Jacob Miller or George Catlin, may have been motivated more by its subject than by his acquaintance with the artists who painted it; see, e.g., Walter Whitman, "That Indian Gallery," Brooklyn Daily Eagle (July 9, 22, 1846).

17 Charles L. Elliott, Kosmos, no. 35 in the auction catalog for the Splendid Collection of Costly Oil Paintings...being the Private Gallery of F.M.Burt, November 5, 1857, with Whitman lines "If you see a good deal remarkable in me..." as the description of the picture in the catalogue.

18 "Hicks, the American Painter," New Orleans Daily Crescent (April 3, 1838). Bohan also lists "Fine Arts at the West," New Orleans Daily Crescent (April 28, 1848).

19 "City Intelligence," Evening Post (April 21, 1851), 2. David B. Dearinger, "Palmer, Erastus Dow," American National Biography Online.

20 Whitman's articles on Talbot that year include "American Art-Jesse Talbot," Dispatch (May 19, 1850); "Works of Beauty and Talent-The New Art Union of Brooklyn," Brooklyn Daily Advertiser (April 4, 1850); "April Afternoon Ramble," Brooklyn Evening Star (April 30, 1850); and "Talbot's Pictures," Phrenological fournal 17 (February 1853), 45.

21 In the spring of 1851, Talbot was advertising his School of Art in the Evening Post. "Encampment of the Caravan," For the Evening Post (April 29, 1851), 1, signed "W." In the March 21, 1851, Evening Post, 3, a "Letter from Brooklyn" is also signed "W."

22 Whitman, Leaves of Grass (Brooklyn, NY: 1856), 115, 107; available online at the Walt Whitman Archive (whitmanarchive.org)

23 Nile Notes of a Howadji (London: Richard Bentley, 1851) received a good review in the Evening Post (March 25, 1851). Curtis also published accounts of his trips in the Tribune, and Whitman had published in the Tribune by 1850. Bayard Taylor, another well-known traveler, left New York in August 1851 for his travels in Egypt, Syria, and Asia Minor. Curtis writes: "The moon has gathered the golden light in her shallow cup, and pours it paler over a bivouac of camels....For us all the caravans of all Arabian romance are there encamping" (7). Curtis in a letter of 1865 said that he did not know Whitman personally; see Horace Traubel, With Walt Whitman in Camden (9 vols., various publishers), 1: 85-86, available online at the Walt Whitman Archive (whitmanarchive.org).

24 "National Academy of Design," American Repertory (May 1841), 283. The art critic for this journal often signed his articles C, though this one is not signed, and covered National Academy activities and officers very sympathetically. He also said that Talbot's Happy Valley had "many beauties," and in the previous year's National Academy exhibition review, the critic had described a Talbot landscape as unobtrusive and true; see "Review of the Exhibition," American Repertory (June 1840), 359. Mechanic, "Letter to the Editor," Morning News (October 11, 1845), 2, and Mechanic, Morning News (October 22, 1845), 2.

25 "National Academy of Design," Morning Courier and Enquirer (May 8, 1852), 2.

26 "National Academy of Design," Evening Mirror (April 30, 1852), 3. Thomas P. Rossiter married the daughter of Eleazer Parmly, a well-to-do dentist, with a practice on Bond Street, and extensive real estate holdings, in 1851. 
27 The May 10, 1851, National Academy exhibition review in the Tribune says that Talbot hardly advances in his landscapes, and accuses him of repeating the same mountains, lakes, and deer year after year, in a style of organized unnaturalness (5). This accusation of mannerism also appears in the Courier and Enquirer (he is imitating Thomas Cole) in 1844, and as "want of nature" in a May 23, 1846, Daily Globe (Democratic) review. The New York Herald, "National Academy of Design-Cutting Criticism" (June 13, 1842), 1, agrees that Talbot imitates Cole too much, but is happy that his current work does not "convey such an impression of dirt and misery as did his 'Happy Valley' of last year - but there is nothing of the natural, and to our feeling less than nothing of the poetical about these Landscapes." The New York Spectator (connected with the Whig Commercial Advertiser), "Landscape Paintings" (December 23, 1840), 2, had earlier praised Talbot for resembling Cole, and for his exalted thoughts and poetical feeling. Before Curtis, Talbot had earlier gotten better notices in the Tribune; "National Academy" (May 27, 1844), 2, in regards to no. 56, "altogether equal to most of the better pictures of this kind in any country." The (Democratic) Day Book in 1850 was still praising Talbot for painting the "soul of a landscape," a phrase the Sunday Mercury considers "foggy nonsense" (September 8, 1850), 2.

28 "American Art-Jesse Talbot," Dispatch (May 19, 1850). Whitman, in "Talbot's Pictures," American Phrenological fournal (February 1853), 45, mentions that a New York journal (presumably Whitman's own article in the Dispatch) has regretted that Talbot's Encampment on the Desert is not in the National Academy exhibition even though it deserves commendation. Whitman here also praises Talbot's illustrations of Cooper, and observes that a reproduction of his warm and glowing Christian and the Cross is owned by Walter Whitman.

29 "National Academy of Design," Dispatch (June 2, 1850). Bohan identifies the author as Whitman also.

30 Herald (April 20, 1839), 2, for example, heralds Stout's sculpture of Queen Victoria as an "Extraordinary Work of Genius" opening a new Era of American Art. 